\title{
Legal Grounds for Social Work Organization in Rural Communities of Ukraine
}

\author{
By Oksana Vasiuk ${ }^{1}$, Olena Gulac ${ }^{2}$, Vasyl Shust ${ }^{3}$, Svitlana Marchenko ${ }^{4}$, \\ Andrii Halai ${ }^{5}$, Viktoriia Halai ${ }^{6}$
}

\begin{abstract}
One of the forms of social work organization in rural areas is the work of united territorial communities created in the course of administrative reform in Ukraine. Such social services in the community can be developed on the basis of a local school, turning it into a comprehensive center of social work with children and adults, families, the elderly and the disabled. The center can employ social educators and social workers, cultural organizers, medical social workers, psychologists. Lawyers, economists and other specialists can be involved as consultants. Analysis of socioeconomic problems of the modern Ukrainian village allows to design the main directions of social work in the community: socio-pedagogical patronage at the place of residence; individual social patronage; programs of individual support of children and parents "at risk"; advisory points; charity events; pedagogical psychotherapy; educational courses for children and parents; initiative groups, clubs of assistants of social pedagogues; employment of adolescents and young people. During our research, villages with a high, medium and low level of organization of social work were identified. Along with the negative tendencies, sprouts of a new, creative attitude to work with the inhabitants of rural areas were revealed. This work is based on a systematic approach to the organization of institutions and associations of socio-educational and cultural orientation.
\end{abstract}

Keywords: administrative reform, social work, rural community, united territorial community

\section{Introduction}

One of the most common trends in public life in almost all civilized countries in the second half of XX century was social work in the community. It included the study of needs, planning and implementation of local social programs, orientation to care for the place of residence, encouragement of local initiatives for human capital development. In general, the idea of activating the structures of civil society was put forward as a response to the problems and gaps in public policy in the social sphere (Spergel, 1994; Payne, 1997). Such ideas have spread almost all over the world - in the capitalist

\footnotetext{
$\mid{ }^{1}$ Dr., Professor of the Department of Pedagogy of the National University of Life and Environmental Sciences of Ukraine

${ }^{2} \mathrm{PhD}$., Associate Professor of the Department of Administrative and Financial Law of the National University of Life and Environmental Sciences of Ukraine

${ }^{3} \mathrm{PhD}$., Associate Professor of the University Department of Physical Education, Sports and Human Health of the Vernadsky Taurida National University

${ }^{4} \mathrm{PhD}$., Associate Professor of the Department of Land and Agricultural Law of the Taras Shevchenko National University of Kyiv

${ }^{5}$ Dr., Professor of the Department of Constitutional, Administrative and Financial Law of Ternopil National Economic University.

${ }^{6}$ Dr., Professor of the Department of Civil and Labour Law of State University of Economics and Technology.
} 
countries of Western Europe and North America, in the former communist countries of Europe and Asia, in the rapidly developing countries of the Pacific, in the less developed countries of Africa, Asia and Latin America. In these regions, there are signs of crisis of statehood, similar to modern Ukraine, steps are being taken to deinstitutionalize and decentralize the management of the social sphere. Nation-states are no longer perceived as entities capable of meeting all the needs of their citizens. Life becomes more individualized. The most important aspects of human life are realized not in large organizations, but in small groups that best meet the specific needs of this person, including spiritual and cognitive.

The study presented in the article is based on a system-activity approach. In studying the general background of social change in the rural community also used a non-systemic approach, the importance of which increases due to the growing dynamics of social change, the ambiguity of the life context, instability and diversity of society. The analysis of the practice of social work in the Velikodimersk village united territorial community of Brovary district of Kyiv region and the assessment of the effectiveness of the practical activities of social workers were conducted on the basis of a questionnaire of community residents.

Socio-legal problems of the Ukrainian village are revealed in the dissertation and other researches of V.F. Gaydardzhi (substantiation of pedagogical conditions for improving the activities of club facilities) (Gaydardzhi, 1993); V.V. Fershtey (study of the process of education of a harmonious personality in the conditions of a rural educational complex) (Fershtey, 1997); Yu.M. Klyuchko and P.A. Clich (study of social education in rural areas) (Clich, 1993; Klyuchko, 1998); O.V. Gafurova, M.A. Deinegi, W.M. Yermolenko (legal problems of social development of the village) (Gafurova, 2015; Yermolenko, 2020), A.M. Stativka (Stativka, 2007) and others.

Valuable in our case are studies on such important issues as the preparation of students of pedagogical specialties for socio-pedagogical activities in rural areas. These include the dissertation of O.Ya. Mezhyrytsky (Mezhyritsky, 2003), L.A. Yadvirshys (Yadvirshys, 2001), monograph by O.G. Maksymova (Maksimova, 2001).

The most thorough in the perspective of our study we consider the collective work of Belarusian scientists under the leadership of MP Guryanova (textbook for the training of social educators for the village) (Guryanova, 1995) and "Guidelines for social workers of rural and urban centers of the SSSDM" (Komarova, 2005). The analysis of these sources will give us the opportunity to identify the main subjects of socio-pedagogical activities in the countryside and reveal their main directions.

The social function in rural communities should include preventive work to protect the environment, the regulatory framework for environmental function. Some issues of bringing the relevant standards to European standards are given in the works: "Cooperation of Ukraine and the European Union in the Ecological Sector: Directions and Prospects"( Gulac, 2019), "New Approaches to Providing of Environmental Management in Ukraine on the Way to Euro Integration" (Dubchak, 2019), "Legal provision of protection and rational use of land resources" (Kurilo, 2007), "Waste Management at the Local Level in the EU and Ukraine" (Ladychenko, 2020), "Legal Regulation of Energy Safety in Ukraine and the European Union: Problems and Perspective" (Shulga, 2019) and "Ecological court as the guarantee of protection of 
rights of human and citizens" (Krasnova, 2019).

\section{Main Problems of Rural Residents}

Currently, the main problems of rural residents are the next: unemployment; poor transport links; unsatisfactory organization of leisure and medical care, water supply, gas supply; low level of household services; fuel and heating supply. The work of schools and preschools needs to be improved. In a number of settlements, preschools are closed, primary schools are closed due to a lack of students, and there are not enough buses to deliver students to neighboring villages where schools still operate. All these reasons, in turn, cause the emergence of various negative antisocial phenomena: alcoholism, drug addiction and more. The situation is complicated by the sharp deterioration of health in Ukraine, which is associated primarily with the Chernobyl accident, mismanagement, poor nutrition. Mortality in rural areas exceeds birth rate. These negative factors are a consequence of the incompleteness of agrarian, land and administrative reforms, which play a key role in the formation and development of rural areas. This all has led to job losses, and as a consequence to the migration of the rural population to large cities, which significantly worsens the formation of the rural structure by major age groups, but also the prospects of preserving not only demographic but also labor potential of rural areas as a significant component of national "human" capital.

The changes in the content of the social environment of the village directly affect the formation of the personality of the child, adolescent and young person. Naturally, in pedagogical research on this problem and assessment of educational opportunities of rural society, among the tasks of social pedagogy of the village called the need to restore the educational function of the rural community and strengthen the educational function of the rural family (Guryanova, 1995).

\section{Organization of Activities at the Community Level}

Traditionally, it is believed that the work of centralized government agencies is characterized by a high degree of bureaucracy and low efficiency, and their funding does not provide adequate quality of service. The organization of activities at the community level is seen as more acceptable, efficient and less burdensome for the state budget. It is known that if a person has a choice, he prefers to be helped at home and preferably by close people. In this case, the community performs the function of organizing social relations and is an intermediate link between the macrosystem of the community as a whole and the microsystem of family and personal support. The community as a level of social work is attractive also considering the possibility to combine formal and informal types of assistance. Thus, in the United Kingdom there is a special law governing the relationship in the provision of community assistance, according to which it is possible to involve non-governmental organizations in the provision of services to be provided by public organizations (on the basis of the so-called social contract). Another point that affects the development of community work in the world is the process of total globalization, associated with technological progress, which, not surprisingly, gave rise to 
a new type of thinking and the need for self-identification, a sense of belonging to a particular group. a community, not a "global village".

These social and economic moments led to a gradual reorientation of views - from state social care to work in the community. Of course, the community is not seen as a certain territory or just a set of people, but as an ideal structure, a symbol that embodies people's ideas about certain forms of social life. This construction is social because it is based on the support, unanimity and mutual understanding of people, which creates a positive charge of energy and cements social ties (Butenko, 2019).

Community members are united by place of residence, ethnicity, religion, or something else. They realize the common interest and they can organize collective action. The community of one building can organize a collective action to prevent the construction of a parking instead, of a playground in front of the windows of their house. A person in the community aqua a public identity. With this identity a person obtain a certain emotional responsibility, a sense of belonging to a larger unit and a certain loyalty to it (Sofii, 2001).

In Ukraine, the impetus to the development of social work in the community are the next several factors:

- deterioration of the material and psychological situation of socially vulnerable groups, and thus the growing need for new social services and programs;

- inability of state, especially inpatient / boarding institutions of social protection, to meet the needs of people, in particular the need to be integrated into the social environment;

- formation of social work as a profession, the emergence of professionals who have an idea of the possibilities and benefits of organizing work at the place of residence or in communities of interest.

\section{Forms of Social Work in the Community}

Analyzing the forms of social work in the community, J. Rothman (1968) identified three main areas of social work in the community: 1) development of the settlement (community development projects, development of self-help groups, etc.); 2) social planning (program development); 3) social action (reforms in favor of low-income clients) (Gilbert, 1994). Summarizing the Western experience, it can be argued that forms of community work include a number of both general social and specific activities: providing services, studying the problem, preparing expert opinions, applying for subsidies, working with the media, negotiations, agreements, conferences, strikes, boycotts, public hearings, civil disobedience, community advocacy, legislative or executive action and. Despite the various theoretical models, all employees must have a set of knowledge, skills and methods of working in the community.

Usually the community worker's tasks are:

- establishing and maintaining contacts with individuals, groups and organizations;

- trade unit development, community resources and needs assessment;

- development of strategic analysis and planning of goals, objectives and priorities;

- supporting groups creating;

- supporting the activity and effective development of groups; 
- productive work with conflicts within and between groups and organizations;

- cooperation and negotiations with other agencies and professions;

- effective intervention in policy development and implementation, including establishing contacts with local politicians;

- oral and written communication with individuals, groups and organizations;

- working with specific people, including counseling;

- resource management, including staffing and budget;

- supporting the groups and organizations in resources obtaining, for example with use of applications for grant;

- progress monitoring and evaluating, and also the most efficient use of resources;

- deductions from groups and/or ensuring effective termination of groups activity.

- development, monitoring and evaluation of equal opportunity strategies (Stativka, 2007).

The main tasks of a social worker are: to develop home-based, day-care and temporary care services to enable people to live in their own homes where appropriate; support of caregivers; coordination of services at the place of residence; ensuring the rational use of funds of those who pay for services in the community. In general, social workers use such modern methodological approaches as: 1) conceptual analysis: data collection, determining the number of problems, assessment the urgency of each of them, goals clarifying, policy alternatives choosing and policy results evaluating; 2) cooperation promoting: creating the formations for planning and decision-making, nominating the leaders, forming group cohesion, mobilizing energy and facilitating connections, discussing the conditions and exchanging of views between the parties involved in solving the problem. New ideas for local community development can change perceptions of political opportunities, but only if the community forces these ideas to work. To develop and use their community skills, the local community needs certain structures and organizations. Historically, local communities have relied mainly on two structures: public meetings (forums) and public associations. These structures created a "public space" in the local community (Skochilyas, 2001). Thus, the social worker needs to cooperate with such public associations and develop local initiatives in the community, so that the "public space" helps to solve or at least reduce social problems and conflicts.

Given the emergence of social services in communities (for example, Hesed professional social services of Jewish communities, Kyiv charity to help people with intellectual disabilities "Sources", which implements community work programs; innovation services supported by the Ukrainian Social Investment Fund), distribution of the practice of temporary family care for orphans and informal care (especially in villages, for lonely elderly and disabled people), empowerment of local governments, training of social workers must include familiarity with various models and methods of work in communities practiced in other countries. Ultimately, this will form a professional idea in our country about the advantages and limitations of this area of professional activity of a social worker (Semigina, 2001).

Community-oriented social workers must have a certain set of knowledge, skills and abilities. Today, the village is understood as a single socio-economic, territorial complex, which includes the rural population, a set of social relations related to its activities, and 
the territory and material objects that are located in this area (Komarova, 2005). The differences that exist in the socio-economic situation of rural and urban residents directly affect the activities of social workers in rural areas. The Law of Ukraine "On the Priority of Social Development of Rural Areas and the Agro-Industrial Complex in the National Economy" of May 15, 1992 is aimed at creating equal opportunities for all citizens who permanently live and work in rural areas to meet social, cultural, educational and household needs. however, its effectiveness was zero due to the declarative nature of its norms and the lack of funding for measures provided by law.

Today, the features of the rural micro-society include conservatism, less mobility for change, openness and sustainability of life, etc. Historically formed approaches to raising children, people's attitudes, and everyday life are still partially preserved in the countryside. However, the displacement of moral and ethical values towards permissiveness and local community (Skochilyas, 2001). Thus, the social worker needs to cooperate with such public associations and develop local initiatives in the community, so that the "public space" helps to solve or at least reduce social problems and conflicts. Given the emergence of social services in communities (for example, Hesed professional social services of Jewish communities, Kyiv charity to help people with intellectual disabilities "Sources", which implements community work programs; innovation services supported by the Ukrainian Social Investment Fund), distribution of the practice of temporary family care for orphans and informal care (especially in villages, for lonely elderly and disabled people), empowerment of local governments, training of social workers must include familiarity with various models and methods of work in communities practiced in other countries. Ultimately, this will form a professional idea in our country about the advantages and limitations of this area of professional activity of a social worker (Semigina, 2001).

Community-oriented social workers must have a certain set of knowledge, skills and abilities. Today, the village is understood as a single socio-economic, territorial complex, which includes the rural population, a set of social relations related to its activities, and the territory and material objects that are located in this area (Komarova, 2005). The differences that exist in the socio-economic situation of rural and urban residents directly affect the activities of social workers in rural areas. The Law of Ukraine "On the Priority of Social Development of Rural Areas and the Agro-Industrial Complex in the National Economy" of May 15, 1992 is aimed at creating equal opportunities for all citizens who permanently live and work in rural areas to meet social, cultural, educational and household needs. however, its effectiveness was zero due to the declarative nature of its norms and the lack of funding for measures provided by law.

Today, the features of the rural micro-society include conservatism, less mobility for change, openness and sustainability of life, etc. Historically formed approaches to raising children, people's attitudes, and everyday life are still partially preserved in the countryside. However, the displacement of moral and ethical values towards permissiveness and irresponsibility, changing the attitude to school and library as a center of culture, worsens the socialization of children, schoolchildren and youth, the activities of educational institutions in rural areas (Yadvirshys, 2001).

The reasons for the shortcomings and problems of social work in rural society, such as the disintegration and weakness of social institutions, the uncertainty of the functional 
responsibilities of social workers is influenced primarily by the underestimation of the role of social workers in rural areas, including libraries. on the need to preserve which was emphasized at the parliamentary hearings in the Committee of the Verkhovna Rada of Ukraine on Culture and Spirituality on "Development of rural libraries as information and cultural centers", because in its most of them remain the only cultural and information institutions in rural areas (Komarova, 2005).

There are three main areas of social work strategy in rural areas:

- the first - the main measures (policy to promote social work in rural areas), the creation of favorable conditions (social conditions for the opportunities of the rural community), cooperation of rural institutions (prevention of bad habits);

- the second - a social worker's practice to solve social problems of life in specific jobs;

- the third - direct work with the individual and his immediate environment - family and peers (Komarova, 2005).

\section{Legal Basis of Social Work in the Community}

The subjects of social work are state and public organizations, individuals who implement social policy and provide social assistance to various categories of the population. Objects of social work - individuals or social groups that need help and support in the process of their socialization. The object of social work in its broadest sense is all citizens (Zvereva, 2003). Under the Law of Ukraine "On Social Services" of January 17,2019 , the subjects of the system of social services are: authorized bodies in the field of social services; recipients of social services; social service providers; association of employees of the social services system; association of social service providers; association of recipients of social services. The above-mentioned subjects of the system of providing social services cooperate at all stages of implementation of this Law, in particular regarding: 1) determination of the needs of the population of the administrative-territorial unit / territorial community in social services; 2) development and implementation of programs for the provision of social services, developed based on the results of determining the needs of the population of the administrative-territorial unit / territorial community in social services; 3) organization, financing and provision of social services; 4) monitoring the provision of social services, assessing their quality and monitoring compliance with the requirements established by the legislation on social services (About social services, 2019).

Currently, the main body that coordinates socio-pedagogical work in the countryside is the village / settlement Center for Social Service (hereinafter - CSS). The legal status of CSS is defined by the Law of Ukraine "On Social Work with Children and Youth" of June 21, 2001. The purpose of its work is to provide psychological, socio-pedagogical, medical, economic, informational, legal and other social services needed by rural youth. They are designed to provide the organization and conduct of social services, social support and patronage, social prevention and rehabilitation.

One of the important activities of the CSS is to involve the rural community in working with families, children and youth, support and development of the volunteer movement (Semigina, 2001; Centers of social services, 2004).

The settlement / village center, which has the status of a legal entity, is created by the 
decision of the settlement / village council and carries out its activities in accordance with the Regulations on the settlement / village center of social services for families, children and youth, approved by the settlement / village council (regional) center of social services for families, children and youth (Semigina, 2001).

Social services are ensured by providers of social services of the state, communal, nonstate sectors, regardless of funding sources in accordance with state standards of social services approved by the central executive body, which ensures the formation of state policy in the field of social protection. services, in particular at each stage of their provision and determine the content and scope, norms and standards, conditions and procedure for providing evaluative service quality indicators (About social services, 2019).

CSCs guide directly the activities of the community (relatives, neighbors, activists, public representatives); extracurricular institutions (clubs, public associations): educational institutions of various types (secondary schools, higher educational institutions, vocational schools); services of various directions (social services for young people of different levels; hospitals, dispensaries, libraries). In the district, as a rule, there is a service for minors, a board of trustees, a department of justice, an employment center, which are involved in solving socio-pedagogical problems of the village (Semigina, 2001). In their activities, CSS are guided by the following principles: legality, observance and protection of human rights, accessibility, confidentiality, responsibility for compliance with ethical and legal norms, voluntariness in accepting assistance (Centers of social services for youth in Ukraine, 2004).

Courses of action of specialists of rural / settlement CSS are: organization of youth assistance, provision of social services to youth (socio-economic, informational, sociopedagogical); organization of youth leisure, mass events (holidays, competitions, entertainment, thematic discos, sports competitions); prevention of negative phenomena in the youth environment, work of a mobile counseling center; promotion of a healthy lifestyle; participation in the work of the board of trustees, the service for minors; work with children, families, youth; creation of a data bank (certification) of privileged and other categories of youth, disadvantaged families; support of volunteer activity; cooperation with the school; career guidance work with young people (Semigina, 2001). Currently, CSS in the countryside are represented by one position of a social worker who actively cooperates with the cultural and leisure complex (village club, library, school, sports facilities). The head of the village (settlement) council coordinates the joint actions of different structures and the organization of social work in the rural community. It should be added that the social educator / rural worker, in addition to solving the sociopedagogical problems of children, adolescents and young people, is concerned with solving various situations of people of all ages. Thus, the clients of the community social educator are: preschoolers, schoolchildren, youth, adults, the elderly.

\section{Conclusions}

Thus, it should be concluded that plenty of researchers are currently dealing with rural issues, apparently realizing that in modern conditions the organization of social work in rural society is at a lower level than in urban areas, and this is due to many 
reasons, among which it is possible to mention the following: insufficient assistance of state bodies, public organizations, private investors; lack of skilled human resources. The living conditions and the environment in the countryside are quite difficult. To improve the current situation, social work in the countryside requires special techniques, methods of managing the social situation, special training to work in a rural society. One example of social work development in rural areas in the context of agrarian, land and administrative reforms in Ukraine should be the organization of a comprehensive service that will provide assistance to various categories of the population, thereby maintaining the optimal level of living for rural population. We strongly believe that the development of social work in rural society should be seen as a constructive social transformational change in the universal context, which will lead to a positive exit of Ukraine from the difficult socio-economic situation, and, consequently, to the revival of the village as one of the main goals of state agricultural policy.

\section{References}

About social services: Law of Ukraine from 17.01.2019. № 2671. Retrieved from: https://zakon.rada.gov.ua/laws/show/2671-19\#Text.

Butenko E.V., Loshakova Yu.A. (2019). Sustainable land use and its assessment: world trends. Land management, cadastre and land monitoring. № 3, p. 37-47. Retrieved from: https://doi.org/10.31548/zemleustriy2019.03.04.

Centers of social services for youth in Ukraine. Gos. social center. services for youth, Ministry of Ukraine for Family, Children and Youth. K., 2004. 28 p.

Clich P.A. (1993). Social education of adolescents in microsociety, dissertation of Cand. ped. Science, Lutsk, $159 \mathrm{p}$.

Fershtey V.V. (1997). Education of the harmonious person in the conditions of a rural educational complex, dissertation of the candidate. ped. science, Lviv, $291 \mathrm{p}$.

Gafurova O.V. (2015). Legal problems of social development of the village in Ukraine, dissertation Doctor of Law, Kyiv, 477 p.

Gaydardzhi V.F., 1993, Pedagogical conditions for improving the activities of club institutions for vocational guidance of high school students in rural schools, dissertation of Cand. ped. Science, K., 139 p.

Gilbert, Specht., 1994, Social Planning and Organization in Local Communities, Encyclopedia of Social Work, V. 3, M., P. 252.

Gulac O., Dubchak L., Iarmolenko I., Yanchuk J. (2019). Cooperation of Ukraine and the European Union in the Ecological Sector: Directions and Prospects. European Journal of Sustainable Development. Volume 8, № 1, pp. 22-30. Retrieved from: http://ojs.ecsdev.org/index.php/ejsd/article/view/762

Gulac O., Goshovska V., Goshovskyi V., Dubchak L. (2019). New Approaches to Providing of Environmental Management in Ukraine on the Way to Euro Integration. European Journal of Sustainable Development. Volume 8, № 2, pp. 45-56. Retrieved from: http://ecsdev.org/ojs/index.php/ejsd/article/view/793/788

Guryanova M.P. (1995). Rural school and social pedagogy: a manual for teachers, Minsk, Amalfey, 448 p.

Klyuchko Yu.M. (1998). Ways of organizing socially-oriented communication of youth in the process of functioning of the pedagogical system "Club - library", dissertation of Cand. ped. Science, Kyiv, $205 \mathrm{p}$.

Krasnova, Yu.A., Deineha, M.A., Honcharuk, L.Yu., Svyatchenko, L.O. (2019). Ecological court as the guarantee of protection of rights of human and citizens. Bulletin of NAS RK, 2019, № 4, P. 185191.

Kurilo V.I., Kichilyuk T.S., Yermolenko V.M. (2007). Legal support of protection and rational use of land resources: Textbook. Kyiv, Magister XXI cent., 248 p. 
Ladychenko V., Melnychuk O., Golovko L., Burmak O. (2020). Waste Management at the Local Level in the EU and Ukraine. European Journal of Sustainable Development 9 (1), 329-329.

Maksimova O.G. (2001). Preparing future teachers to perform professionally determined social functions, Monograph, Cheboksary, $154 \mathrm{p}$.

Methodical recommendations for social workers of rural and settlement centers of SSFCY / N.M. Komarova, O.V. Vakulenko, A.H. Zinchenko [etc.]. K., 2005. 176 p.

Mezhyritsky O.Ya. (2003). Preparing students for socio-pedagogical activities in rural areas, dissertation of Cand. ped. Science, Lugansk, 215 p.

Payne M. (1997). Community as the basis of social policy and social action, The relationship of social work and social policy, M., Aspect Press, pp. 48-50.

Semigina T. (2001). Work in the community as a component of the social worker, Social policy and social work, № 4.

Shulga, I., Kurylo, V., Gyrenko, I., Savych, S. (2019). Legal Regulation of Energy Safety in Ukraine and the European Union: Problems and Perspective. European Journal of Sustainable Development, Volume 8, № 3, 439-447.

Social work in Ukraine, 2003, Edited I.D. Zvereva, G.M. Laction, K., Scientific World, 233 p.

Sofii O., Klemanska L. (2001). The community is ... Some thoughts on the course "Community Development" (IMHS). Public Initiatives, № 3.

Spergel I., Territorial community: evolution, 1994, Encyclopedia of Social Work, V. 3, M., pp. 315-320.

Stativka A.M. (2007). Organizational and legal issues of rural social development in Ukraine, Monograph. H., Right, $208 \mathrm{p}$.

Yadvirshys L.A. (2001). Professional preparation of a teacher for social and pedagogical activity: dissertation. ped. Sciences, Bryansk, 221 p.

Yermolenko V.M., Hafurova O.V., Deineha M.A. (2020). Legal principles of rural medicine development in the context of medical reform in Ukraine, Bulletin of the National Academy of Sciences of the Republic of Kazakhstan, Issue 1. P. 113-120. 